\title{
PENGARUH ARUS LISTRIK DAN WAKTU PROSES TERHADAP KETEBALAN DAN MASSA LAPISAN YANG TERBENTUK PADA PROSES ELEKTROPLATING PELAT BAJA
}

\author{
Daud Topayung ${ }^{1}$ \\ ${ }^{1)}$ Program Studi Teknik Mesin Politeknik Negeri Manado, 95252 \\ email: dtopayung@gmail.com
}

\begin{abstract}
ABSTRAK
Penelitian menggunakan hukum Faraday untuk analisis teoritis dan metode statistik untuk analisis hasil pengukuran. Hasil teoritis, Ketebalan: Tmaks $=0.116461 \mathrm{~mm}$, Tmin $=0.028423 \mathrm{~mm}$. Massa: Mmaks $=5.2100$ gr, Mmin $=1.3025$ gr. Hasil pengukuran, Ketebalan: Tmaks $=0.109$ $\mathrm{mm}$, Tmin $=0.026 \mathrm{~mm}$. Massa: Mmaks $=4.8516 \mathrm{gr}$, Mmin $=1.1902$ gr. Ketebalan dan massa lapisan teoritis lebih besar dari hasil pengukuran. Perbedaan keduanya: Tmaks $=0.007 \mathrm{~mm}$ $(6.12 \%)$, Tmin $=0.002 \mathrm{~mm}(7.35 \%)$, Mmaks $=0.3564 \mathrm{gr}(6.88 \%), \mathrm{Mmin}=0.1123 \mathrm{gr}(8.62 \%)$. Untuk hasil teoritis dan hasil pengukuran: Tmaks and Mmaks diperoleh pada arus listrik $=8$ Ampere dan waktu proses 60 menit, Tmin dan Mmin diperoleh pada arus listrik $=4$ Ampere dan waktu proses 30 menit
\end{abstract}

Kata kunci: anoda , arus listrik , asam kromik, Elektroplating, katoda

\section{EFFECT OF ELECTRIC CURRENT AND PROCESS TIME THE THICKNESS AND MASS LAYER FORMED ON ELECTROPLATING PROCESS STEEL PLATES}

\begin{abstract}
Research using Faraday's law for the theoretical analysis and statistical methods to analyze the results of measurements. Theoretical results, Thickness: Tmaks $=0.116461 \mathrm{~mm}$, Tmin $=$ $0.028423 \mathrm{~mm}$. Mass: Mmaks $=5.2100 \mathrm{gr}, \mathrm{Mmin}=1.3025$ gr. Results of measurement, Thickness: Tmaks $=0.109 \mathrm{~mm}$, Tmin $=0.026 \mathrm{~mm}$. Mass: Mmaks $=4.8516$ gr, Mmin $=1.1902$ gr. Layer thickness and mass is theoretically greater than the measurement results. Differences both: Tmaks $=0.007 \mathrm{~mm}(6.12 \%)$, Tmin $=0.002 \mathrm{~mm}(7.35 \%)$, Mmaks $=0.3564 \mathrm{gr}(6.88 \%)$, Mmin $=0.1123$ gr $(8.62 \%)$. For the theoretical results and measurements: Tmaks and Mmaks obtained at an electric current $=8$ Amperes and 60 minutes, Tmin and Mmin obtained $=4$ Amperes of electric current and 30 minutes
\end{abstract}

Keywords: anode, electric current, chromic acid, Electroplating

\section{PENDAHULUAN}

Capaian kualitas dari suatu produk dapat diperoleh dengan berbagai penerapan metode pengerjaan selama tahapan produksi, salah satu diantaranya adalah penerapan proses/pengerjaan akhir (finishing) terhadap produk pada tahapan akhir dari keseluruhan rangkaian proses pembuatan. salah satu jenis proses yang termasuk dalam kelompok ini, adalah proses elektroplating dengan menggunakan bahan pelapis krom (chrome plating). Variabel yang dapat mempengaruhi proses, antara lain tegangan dan arus listrik yang diberikan; waktu atau lamanya proses dilakukan; jumlah titik penyaluran arus; jenis, sifat, konsentrasi atau kepekatan dan temperatur larutan; jenis, luasan jarak Elektroda

Elektroplating dibuat dengan jalan mengalirkan arus listrik melalui larutan antara logam atau material lain yang konduktif. Dua buah plat logam merupakan anoda dan katoda dihubungkan pada kutub positif dan negatif terminal sumber arus searah (DC). Logam yang terhubung dengan kutub positif disebut anoda dan yang terhubung dengan kutub negatif disebut katoda. Ketika sumber tegangan digunakan pada elektrolit, maka kutub positif 
mengeluarkan ion bergerak dalam larutan menuju katoda dan disebut sebagai kation. Kutub negatif juga mengeluarkan ion, bergerak menuju anoda dan disebut sebagai anion. Larutannya disebut elektrolit (Abrianto ,2008)

Pelapisan krom adalah salah satu jenis proses elektroplating dengan menggunakan bahan kromium. Pelapisan dengan menggunakan bahan krom dapat dilakukan pada berbagai jenis logam seperti besi,baja, atau tembaga. Pelapisan krom juga dapat dilakukan pada plastik atau jenis benda lain yang bukan logam, dengan persyaratan bahwa benda tersebut harus dicat dengan cat yang mengandung logam sehingga dapat mengalirkan arus listrik. Pelapisan krom menggunakan bahan dasarasam kromat, $\left(\mathrm{H}_{2} \mathrm{CrO} 4\right)$ dan asam sulfat $\left(\mathrm{H}_{2} \mathrm{SO}_{4}\right)$ sebagai bahan pemicu arus, dengan perbandingan campuran yang tertentu. Perbandingan yang umum bisa 100:1 sampai 400:1. Jika perbandingannya menyimpang dari ketentuan biasanya akan menghasilkan lapisan yang tidak sesuai dengan yang diharapkan. Faktor lain yang dapat berpengaruh pada proses pelapisan krom ini adalah temperatur larutan dan besar arus listrik yang mengalir sewaktu melakukan pelapisan. Temperatur pelapisan bervariasi antara (35 $\mathrm{s} / \mathrm{d}$ 60) ${ }^{\circ} \mathrm{C}$ dengan besar perbandingan besar arus $(0,14$ s/d 0,43$) \quad \mathrm{A} / \mathrm{cm}^{2} \quad$ Bahan Elektroda yang digunakan pada jenis pelapisan ini adalah krom $(\mathrm{Cr})$ sebagai anoda (kutub positif) dan benda yang akan dilapis sebagai katoda (kutub negatif). Jarak antara elektroda tersebut antara (9 $\mathrm{s} / \mathrm{d} \quad 29) \mathrm{cm}$. Sumber listrik yang digunakan adalah arus searah dengan beda potensial berkisar antara 4 s/d 25 Volt (Lawrence, 1984).

Hubungan antara beda potensial dalam elektrolit dan kekuatan arus listrik yang mengalir menurut Hukum Ohm yaitu (Sukardjo, 1985):

$\mathbf{I}=\frac{\mathbf{V}}{\mathbf{R}}$

$\mathrm{I}=$ Kuat arus listrik (Ampere) $; \mathrm{V}=$ Beda potensial (Volt); $\mathrm{R}=$ Tahanan listrik (ohm)

Besarnya listrik yang mengalir yang dinyatakan dengan Coulomb adalah sama dengan arus listrik dikalikan dengan waktu.

$\mathrm{Q}=\mathrm{I} . \mathrm{t}$

$\mathrm{Q}=$ Muatan listrik (Coulomb); $\mathrm{I}=$ Kuat arus listrik (Ampere); $\mathrm{t}=$ Waktu (detik)
Michael Faraday pada tahun 1833 menetapkan hubungan antara kelistrikan dan ilmu kimia pada semua reaksi elektrokimia. Dua Hukum Faraday ini adalah (Sukarjo, 1985).

\section{Hukum I :}

Massa zat yang terjadi akibat reaksi kimia pada elektroda berbanding lurus dengan jumlah muatan listrik yang mengalir pada larutan elektrolit selama elektrolisis.

$\mathrm{m}=\frac{\mathbf{E}}{\mathbf{F}} \mathrm{I} \cdot \mathrm{t}$

$\mathrm{m}=\frac{\mathbf{B A}}{\mathbf{n}} \cdot \frac{\mathrm{I} \cdot \mathbf{t}}{\mathbf{F}}$

$\mathrm{m}=$ massa zat $(\mathrm{gram}) ; \mathrm{E}=$ berat eqivalen (gram); F = Bilangan Faraday; $\mathrm{I}=$ kuat arus listrik (Ampere); $\mathrm{t}=$ Waktu (detik); $\mathrm{BA}=$ Berat atom unsure; $\mathrm{n}=$ Jumlah mol zat.

Untuk perak telah diperoleh bahwa 1 Coulomb menghasilkan $1,118 \mathrm{mg}$ perak. Untuk mengendapkan 1 grek perak atau 107,880 gr perak, diperlukan 107,880/0,001118 = 96.494 Coulomb. Listrik sebesar ini dikenal sebagai 1 Faraday.

\section{Hukum II :}

Massa berbagai zat yang terjadi selama elektrolisis, berbanding lurus dengan berat ekivalennya.

Menurut Milikan muatan 1 elektron = 1,602 $\times 10^{-19}$ coulomb, jadi jumlah elektron dalam 1 Faraday adalah $96.494 / 1,602 \times 10^{-19}$ $=6,023 \times 10^{23}$ elektron. Angka inilah yang dikenal dengan Bilangan Avogadro. Jadi 1 Faraday setara dengan $6,023 \times 10^{23}$ partikel dengan muatan tunggal atau 1 grek zat.

Asam Kromat adalah sebuah senyawa kromium $(\mathrm{Cr})$. Senyawa ini memiliki rumus kimia $\mathrm{H}_{2} \mathrm{CrO}_{4}$. Senyawa ini belum pernah diisolasi dalam bentuk murninya. Basa konjugat dari asam ini adalah ion kromat dan dikromat, yang dapat membentuk beberapa garam (misalnya kalium dikromat, $\mathrm{K}_{2} \mathrm{Cr}_{2} \mathrm{O}_{7}$ ). Anhidrida dari asam kromat adalah kromium trioksida, atau disebut juga kromium (VI) oksida, $\mathrm{CrO}_{3}$. Pada asam kromat, dikromat ataupun semua turunannya, atom kromium mempunyai bilangan oksidasi +6. Larutan asam kromat dibuat dengan cara mengasamkan larutan yang mengandung ion kromat atau dikromat. Larutan ini bersifat oksidator kuat, berwarna merah kecoklatan, jingga atau kuning tergantung konsentrasi kromium (VI). 
Ion adalah

atom

atau sekumpulan atom yang bermuatan listrik. Ion bermuatan negatif, yang menangkap satu atau lebih elektron, disebut anion, karena dia tertarik menuju anoda. Ion bermuatan positif, yang kehilangan satu atau lebih elektron, disebut kation, karena tertarik ke katoda. Proses pembentukan ion disebut ionisasi. Atom atau kelompok atom yang terionisasi ditandai dengan tikatas ${ }^{\mathrm{n+}}$ atau ${ }^{\mathrm{n}-}$, di mana $n$ adalah jumlah elektron yang hilang atau diperoleh. Larutan ion adalah jenis larutan yang mengandung ion yang dapat bergerak bebas sehingga mampu menghantarkan arus listrik. (Lawrence, 2004).

Garam adalah senyawa ionik yang

terdiri dari ion positif (kation) dan ion negatif (anion), sehingga membentuk senyawa netral (tanpa bermuatan). Garam terbentuk dari hasil reaksi asam dan basa. Natrium klorida $(\mathrm{NaCl})$, Garam dalam air merupakan larutan elektrolit, yaitu larutan yang dapat menghantarkan arus listrik.

Redoks (singkatan

dari reaksi reduksi/oksidasi) adalah istilah yang menjelaskan berubahnya bilangan oksidasi (keadaan oksidasi) atom-atom dalam sebuah reaksi kimia. Hal ini dapat berupa proses redoks yang sederhana seperti oksidasi karbon yang menghasilkan karbon dioksida, atau reduksi karbon oleh hidrogen menghasilkan metana $\left(\mathrm{CH}_{4}\right)$, Istilah redoks berasal dari dua konsep, yaitu reduksi dan oksidasi.

\section{METODOLOGI PENELITIAN}

\section{Bahan-Bahan Penelitian :}

- Lempengan Katoda, terbuat dari bahan pelat Baja.

- Lempengan Anoda, dibuat dari bahan Krom

- Larutan elektrolit yaitu Asam Kromat

- Aquabides, HCL-10\% dan NaOH-10\%

\section{Peralatan bantu}

Neraca Analitik, Jangka Sorong, Mikrometer,Stopwatch, Termometer, Heater, Wadah, AVO-meter digital.

\section{Pengambilan data:}

1) pengukuran panjang dan lebar bidang permukaan spesimen (dilakukan sebelum dproses pelapisan dilaksanakan).
2) Pengukuran massa spesimen dan massa anoda (dilakukan sebelum dan setelah proses pelapisan dilaksanakan).

3) Pengukuran ketebalan spesimen (dilakukan sebelum dan setelah proses pelapisan dilaksanakan).

\section{HASIL DAN PEMBAHASAN}

Hubungan antara variabel kuat arus listrik dan waktu proses dengan variabel ketebalan dan massa lapisan yang terbentuk, disajikan pada gambar 1-4.

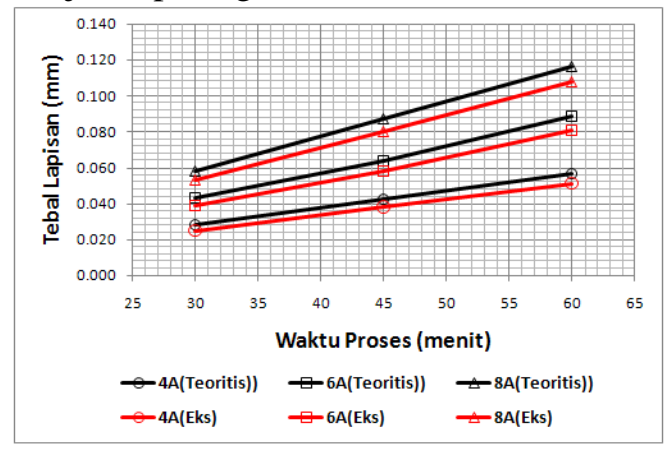

Gambar 1. Hubungan waktu proses dan ketebalan lapisan

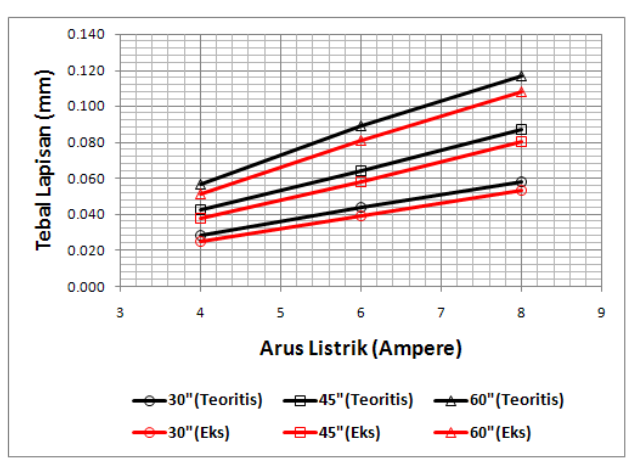

Gambar 2. Hubungan arus listrik dan ketebalan lapisan

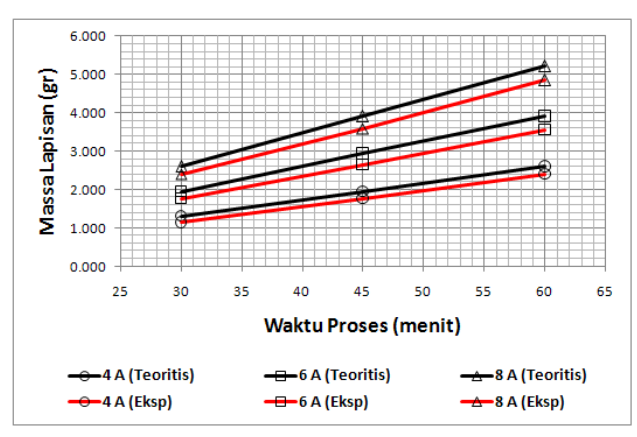

Gambar 3. Hubungan waktu proses dan massa lapisan 


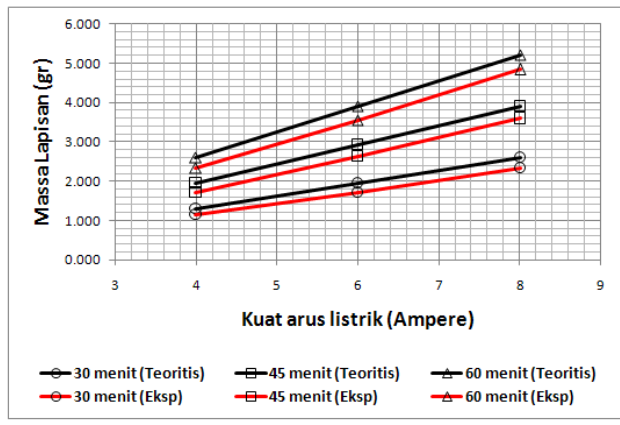

Gambar 4. Hubungan arus listrik dan massa lapisan

Adanya pengaruh besaran "Waktu Proses" terhadap ketebalan lapisan yang terbentuk pada permukaan specimen dapat dilihat pada Grafik-1. Dengan mengamati grafik tersebut, maka dapat terlihat bahwa pada kondisi arus listrik konstan, ketebalan lapisan yang dihasilkan untuk ketiga variasi waktu proses yang digunakan, menunjukkan pola: 30 menit $<45$ menit $<60$ menit. Penjelasan untuk hal ini adalah semakin lama proses berlangsung, maka porsi akumulasi pergerakan elektron dan transfer material pada kedua elektroda juga akan semakin besar.

Sedangkan adanya pengaruh besaran "Kuat arus listrik" terhadap ketebalan lapisan yang terbentuk pada permukaan spesimen dapat dilihat pada Grafik-2. Dengan mengamati grafik tersebut, maka dapat terlihat bahwa pada kondisi dimana waktu proses konstan, ketebalan lapisan yang dihasilkan untuk ketiga variasi kuat arus listrik yang digunakan, menunjukkan pola : 4 Ampere < 6 Ampere < 8 Ampere. Penjelasan untuk kondisi ini adalah semakin besar nilai kuat arus listrik yang digunakan, maka akan menyebabkan elektron lebih reaktif (lebih mudah bergerak), Hal ini juga akan menyebabkan porsi akumulasi pergerakan electron dan transfer material pada kedua elektroda juga akan semakin besar.

Hal lain yang perlu dikemukakan dan berkaitan dengan hasil percobaan ini adalah konsep teoritis mengenai proses elektrokimia yang dikemukakan oleh Faraday, dimana kedua hukumnya menyatakan secara matematis bahwa massa zat yang terbentuk pada suatu proses elektrokimia adalah berbanding lurus dengan kuat arus listrik dan waktu proses. Secara kualitatif hasil perhitungan secara teoritis telah menunjukkan hasil atau pola yang sama dengan hasil yang diperoleh melalui percobaan, walaupun masih terdapat perbedaan secara kuantitatif.

Dari penjelasan tersebut di atas, maka Indikasi adanya Pengaruh kuat arus listrik dan waktu proses terhadap ketebalan lapisan yang terbentuk ditandai dengan terjadinya perubahan nilai ketebalan lapisan jika nilai dari kedua variabel bebas dibuat bervariasi. Pola pengaruh yang teramati adalah berbanding lurus.

Dengan membandingkan data yang ada, maka dapat diketahui bahwa Nilai ketebalan lapisan pada permukaan spesimen yang diperoleh secara teoritis dengan menggunakan perhitungan dasar elektrokimia, lebih tinggi jika dibandingkan dengan nilai ketebalan lapisan yang diperoleh dari pengukuran (eksperimen). Kemungkinan penyebab adalah terletak pada efisiensi proses yang dilaksanakan, dimana kondisinya belum memenuhi kondisi ideal. Misalnya dalam hal penyaluran energi listrik yang diperlukan untuk membangkitkan pergerakan elektron pada kedua elektroda (spesimen dan anoda), termasuk transfer material diantara keduanya yang diangkut oleh ion-ion bermuatan listrik melalui larutan.

Pada pelaksanaan proses pelapisan, baik anoda maupun spesimen (katoda), pemasangannya hanya menggunakan kawat pengait. Kondisi pemasangan seperti ini memungkinkan tidak stabilnya kedudukan kedua elektroda, sebab selama proses berlangsung timbul gelembung dalam larutan sehingga memungkinkan tidak stabilnya kedudukan kedua elektroda. Ketidakstabilan ini tentunya akan mempengaruhi penyaluran arus listrrik atau istilahnya dalam kelistrikan adalah terjadi lose contact. Salah satu indikasi hal ini adalah terjadinya peningkatan temperatur larutan sebagai efek dari tidak tersalurnya energi listrik dengan baik sehingga berubah menjadi panas.

Disamping itu, data yang ada, juga menunjukkan perbedaaan nilai ketebalan lapisan yang diperoleh berdasarkan hasil pengukuran (eksperimen) dan hasil perhitungan (secara teoritis), termasuk nilai maksimum dan minimum dari ketebalan lapisan yang terbentuk. Ketebalan maksimum lapisan diperoleh pada penggunaan arus listrik sebesar 8 Ampere dan waktu proses selama 60 menit, nilainya adalah 0,116461 $\mathrm{mm}$ (secara teoritis) dan 0,109 $\mathrm{mm}$ (hasil 
pengukuran), dimana selisih keduanya adalah $0,007 \mathrm{~mm}(6,12 \%)$, sedangkan ketebalan minimum lapisan diperoleh pada penggunaaan arus listrik sebesar 4 Ampere dengan waktu proses selama 30 menit, nilainya adalah $0,028423 \mathrm{~mm}$ (secara teoritis) dan 0,026 $\mathrm{mm}$ (hasil pengukuran), dimana selisih keduanya adalah $0,002 \mathrm{~mm}(7,35 \%)$.

Selain itu, juga dapat diketahui bahwa massa lapisan pada permukaan spesimen yang diperoleh secara teoritis dengan menggunakan perhitungan dasar elektrokimia, mempunyai nilai yang lebih tinggi jika dibandingkan dengan nilai massa yang diperoleh dari pengukuran (eksperimen), kemungkinan penyebabnya adalah berasal dari faktor-faktor yang juga berhubungan dengan efisiensi proses, misalnya tidak tercapainya kondisi proses yang ideal pada penyaluran arus listrik sehingga energi listrik yang dibangkitkan, kurang efektif menggerakkan elektron pada kedua elektroda, termasuk menggerakkan ion-ion pembawa muatan listrik dalam larutan. Hal ini akan mengakibatkan transfer material diantara kedua elektroda melalui larutan kurang berjalan dengan baik. Indikasi ini juga dapat ditandai dengan adanya endapan material anoda pada dasar wadah penampung. Perbedaaan nilai massa lapisan yang diperoleh berdasarkan hasil pengukuran (eksperimen) dan hasil perhitungan (secara teoritis), termasuk nilai maksimum dan minimum dari ketebalan lapisan yang terbentuk. Massa maksimum lapisan diperoleh pada penggunaan arus listrik sebesar 8 Ampere dan waktu proses selama 60 menit, nilainya adalah 5.2100 gr (secara teoritis) dan 4.8516 gr (hasil pengukuran), dimana selisih keduanya adalah 0.3584 gr $(6,88 \%)$, sedangkan massa minimum lapisan diperoleh pada penggunaaan arus listrik sebesar 4 Ampere dengan waktu proses selama 30 menit, nilainya adalah 1.3025 gr (secara teoritis) dan 1.1902 gr (hasil pengukuran), dimana selisih keduanya adalah 0.1123 gr $(8,62 \%)$

\section{KESIMPULAN}

1) Kuat arus listrik dan Waktu proses berpengaruh terhadap Ketebalan dan Massa lapisan yang terbentuk pada proses elektroplating. Semakin besar arus listrik dan waktu proses yang digunakan, maka semakin besar pula ketebalan dan massa lapisan yang dapat terbentuk. Nilai ketebalan dan massa lapisan yang diperoleh secara teoritis lebih besar dibandingkan dengan nilai yang diperoleh dari hasil pengukuran.

2) Ketebalan maksimum lapisan diperoleh pada penggunaan arus listrik sebesar 8 Ampere dan waktu proses selama 60 menit, sedangkan ketebalan minimum lapisan diperoleh pada penggunaaan arus listrik sebesar 4 Ampere dengan waktu proses selama 30 menit. Hal yang sama, berlaku juga untuk besaran massa, nilai maksimum dari massa lapisan diperoleh pada penggunaan arus listrik sebesar 8 Ampere dan waktu proses selama 60 menit, sedangkan massa minimum lapisan diperoleh pada penggunaaan arus listrik sebesar 4 Ampere dengan waktu proses selama 30 menit.

\section{DAFTAR PUSTAKA}

Abrianto, A. 2008. Dasar-Dasar Proses Elektroplating. http://www.slideshare. net/.

Lawrence, J. 1984 Electroplating Engineering Handbook, $4^{\text {th }}$ Edition. Van Nostrand Reinhold Company, New York.

Lawrence, V.H. 2004. Elemen-elemen Ilmu dan Rekayasa Material. edisi keenam. Erlangga, Jakarta.

Sukardjo. 1985. Kimia Fisika. Bina Aksara, Jakarta.

Rahayu, S.S. 2009. Dasar Teori Elektroplating. http://www.chem-istry.org/. 